\title{
ANALISIS SIKAP DAN KEPUASAN PETANI TERHADAP ATRIBUT ASURANSI USAHATANI PADI DI KABUPATEN KARAWANG JAWA BARAT
}

\author{
Mega Mustika ${ }^{1)}$, Anna Fariyanti' ${ }^{2}$, dan Netti Tinaprilla ${ }^{3)}$ \\ ${ }^{1)}$ Program Magister Sains Agribisnis, Sekolah Pascasarjana Institut Pertanian Bogor \\ ${ }^{2,3)}$ Departemen Agribisnis, Fakultas Ekonomi dan Manajemen, Institut Pertanian Bogor \\ ${ }^{1)}$ megamustika119@gmail.com \\ Diterima 12 April 2019/ Di setujui 23 September 2019
}

\begin{abstract}
Agricultural sector technically has quite high risk of uncertainty, including crop failure level which is caused by climate change, pest attack and disease, flood, dryness, as well as price uncertainty which is at the end harm the farmer. In order to decrease the risk that faced by farmers especially rice farmer, government run Asuransi Usaha Tani Padi (AUTP) program. This research aimed to analyze the farmer's attitude and satisfaction to AUTP attributes in Karawang West Java. Analysis tools that used in this research are Multiatribut Fishbein analysis to observe farmer's attitude and Customer Satisfaction Index (CSI) analysis to detect farmer's satisfaction level to AUTP attribute. The result of this research, found that the most important attributes according to farmer based on the importance level are Penyuluh Pertanian Lapangan (PPL), the number of the claim, direct socialization, farmer group leader and easy access to information. Farmer's satisfaction level to AUTP attributes overall is quite satisfy. Therefore the performance of AUTP attributes level need to be increased, so that the farmer's attitude and satisfaction to AUTP increase. Farmers that have positive attitude and satisfaction tend to follow the program continously and will recommend it to other farmer.
\end{abstract}

Keywords: attitude, CSI, multiatribut fishbein, satisfaction

\begin{abstract}
ABSTRAK
Sektor pertanian secara teknis memiliki risiko ketidakpastian yang cukup tinggi, meliputi tingkat kegagalan panen yang disebabkan oleh perubahan iklim, serangan hama dan penyakit tanaman, banjir, kekeringan serta ketidakpastian harga yang pada akhirnya merugikan petani. Untuk mengurangi risiko yang dihadapi petani, khususnya petani padi, pemerintah menjalankan program Asuransi Usaha Tani Padi (AUTP). Penelitian ini ditujukan untuk menganalisis sikap dan kepuasan petani terhadap atribut AUTP di Kabupaten Karawang Jawa Barat. Alat analisis yang digunakan pada penelitian ini adalah analisis Multiatribut Fishbein untuk melihat sikap petani dan analisis Customer Satisfaction Index (CSI) untuk mengetahui tingkat kepuasan petani terhadap atribut AUTP. Hasil penelitian menemukan bahwa atribut yang paling penting menurut petani berdasarkan tingkat kepantingan adalah Penyuluh Pertanian Lapangan (PPL), jumlah klaim, sosialisasi langsung, ketua kelompok tani dan kemudahan mendapatkan informasi. Tingkat kepuasan petani terhadap atribut AUTP secara keseluruhan adalah cukup puas. Oleh karena itu tingkat kinerja atribut AUTP perlu untuk ditingkatkan, agar sikap dan kepuasan petani terhadap AUTP meningkat. Petani yang memiliki sikap dan kepuasan yang positif akan cenderung mengikuti program secara berkelanjutan dan merekomendasikannya kepada petani lain.
\end{abstract}

Kata kunci: sikap, kepuasan, CSI, Multiatribut Fishb 


\section{Latar Belakang}

\section{PENDAHULUAN}

Secara teknis usaha di sektor pertanian akan selalu dihadapkan pada risiko ketidakpastian yang cukup tinggi. Risiko ketidakpastian tersebut meliputi tingkat kegagalan panen yang disebabkan serangan hama dan penyakit tanaman, perubahan iklim, banjir, kekeringan, serta ketidakpastian harga pasar yang akhirnya merugikan petani. Untuk mengurangi risiko yang dihadapi oleh petani melalui UU No. 19/2013 tentang perlindungan dan pemberdayaan petani pasal 37 ayat (1) yang berbunyi "Pemerintah dan Pemerintah Daerah sesuai dengan kewenangannya berkewajiban melindungi usahatani yang dilakukan oleh petani dalam bentuk asuransi pertanian". Asuransi pertanian dilakukan untuk melindungi petani dari kerugian gagal panen akibat banjir, kekeringan, serangan penyakit, serangan hama, serta dampak perubahan iklim.

Asuransi pertanian menunjukan keberpihakan untuk mengantisipasi risiko kerugian berusahatani. Sejalan dengan penelitian Epitemehin (2011) di Nigeria, yang menyatakan bahwa asuransi pertanian membantu petani mengurangi risiko dengan mengatur pola tanam, membangun irigasi yang baik agar bisa melakukan usahatani pada musim panas. Asuransi pertanian di Indonesia mencakup empat sub sektor, yaitu tanaman pangan, hortikultura, perkebunan, dan peternakan. Asuransi Ternak Sapi (ATS) diujicobakan sejak tahun 2012 dan memperoleh sambutan yang baik dari kalangan. Asuransi Usahtani Padi (AUTP) mulai diperkenalkan dan dilaksanakan sejak Musim Tanam (MT) 2012/2013. Padi sebagai komoditas strategis nasional menjadi salah satu sasaran perlindungan karena kerentanannya terhadap perubahan iklim dan risiko yang ditimbulkannya, oleh karena itu kementerian pertanian pada tahun 2016 menfokuskan uji coba asuransi pertanian hanya untuk komoditas padi (Direktorat Jendral Prasarana dan Sarana Pertanian, 2015).

Asuransi pertanian dinilai layak sebagai sarana untuk mendidik petani meningkatkan produksi dan produktivitas usahataninya, karena dalam pelaksanaan AUTP, petani diharuskan mengikuti cara bercocok tanam yang sesuai dengan anjuran teknis dan mendapat pengawasan dari pihak asuransi. Setiap program baru yang diperkenalkan kepada petani memerlukan penjelasan yang komprehensif terlebih dahulu sebelum diaplikasikan atau diadopsi. Kegiatan sosialisasi informasi tentang AUTP dibutuhkan agar petani dan semua pemangku kepentingan terkait dapat mengerti, memahami, dan mampu melaksanakannya secara mandiri sesuai dengan aturan pelaksanaannya dan mengikuti aturan yang berlaku (Pasaribu, 2016).

\section{Rumusan Masalah}

Kabupaten Karawang dipilih sebagai lokasi uji coba I karena 
merupakan sentra produksi padi dan merupakan daerah yang tingkat kerentanan atau risikonya cukup tinggi, terutama risiko terhadap kondisi yang tidak bisa dikendalikan seperti serangan Organisme Pengganggu Tanaman (OPT), kekeringan dan banjir. Target untuk Kabupaten Karawang pada uji coba I adalah seluas 1.000 ha, namun dikatakan tidak berhasil karena tidak ada petani yang tertarik ikut asuransi pertanian. Sikap petani yang tidak tertarik mengikuti AUTP karena merasa tidak pernah mengalami gagal panen sehingga tidak memerlukan asuransi, serta harus membayar premi sebesar Rp 36.000/ha dirasa cukup memberatkan (Insyafiah dan Wardhani, 2014).

Pada tahun 2016 target AUTP Kabupaten Karawang adalah seluas 15.000 ha dan terealisasi seluas 33.000 ha, tahun 2017 target dinaikan menjadi 50.000 ha dan terealisasi hanya 300 ha. Oleh karena itu, Pemerintah Daerah Kabupaten Karawang berencana akan mensubsidi petani padi untuk ikut AUTP seluas 70.000 ha senilai 2,5 miliyar dan untuk lahan sisanya akan dicarikan dana dari Corporate Social Responbility (CSR) perusahaan yang ada di Kabupaten Karawang agar memberikan subsidi kepada petani untuk ikut AUTP di tahun 2018. Kecamatan Banyusari pada tahun 2017 yang mengikuti AUTP hanya 4 ha dari 3.814 ha total luas lahan sawah, yaitu 2 ha di Desa Jayamukti dan 2 ha di Desa Pamekaran. Hal ini diduga karena petani belum merasakan manfaat serta ketidakpuasan petani dalam mengikuti program asuransi pertanian sebagai upaya untuk mengurangi risiko dalam usahataninya.

Pemerintah khususnya Dinas Pertanian Kabupaten Karawang Jawa Barat dan PT Jasindo harus memiliki pengetahuan mengenai perilaku dari petani. Sikap yang terbentuk pada diri petani akan mempengaruhi cara pandangnya terhadap program AUTP dan akan mempengaruhi keberhasilan program. Sikap petani akan menggambarkan program AUTP apakah sudah berjalan sesuai tujuan, sehingga mengetahui sikap petani terhadap atribut AUTP akan membantu untuk pengembangan program tersebut kedepannya. Kepuasan petani terhadap program AUTP juga perlu dilakukan untuk mengetahui apakah program sudah sesuai dengan harapan petani atau belum. Berdasarkan uraian tersebut di atas, maka permasalahan yang diteliti sehubungan dengan penelitian ini adalah " bagaimana sikap dan kepuasan petani terhadap atribut AUTP di Kabupaten Karawang Jawa Barat?'

\section{Tujuan Penelitian}

Berdasarkan

perumusan masalah yang telah diuraikan di atas, maka tujuan penelitian ini adalah:

1. Menganalisis sikap petani terhadap AUTP

2. Menganalisis kepuasan petani terhadap atribut AUTP 
3. Menganalisis hubungan sikap dan kepuasan petani dalam mengikuti AUTP

\section{METODE PENELITIAN}

\section{Lokasi dan Waktu Penelitian}

Penelitian ini dilakukan di Kabupaten Karawang, Provinsi Jawa Barat. Penentuan daerah penelitian ditentukan secara purposivesampling dengan pertimbangan lokasi penelitian merupakan salah satu sentra padi dan termasuk wilayah yang mengikuti program Asuransi Usaha Tani Padi (AUTP) di Jawa Barat. Waktu pengumpulan data pada penelitian, dilakukan pada bulan April- Mei 2018.

\section{Jenis dan Sumber Data}

Data yang digunakan dalam penelitian ini adalah data primer dan sekunder. Data primer diperoleh melalui survei dan wawancara langsung dengan responden petani padi, dengan bantuan kuesioner. Data sekunder sebagai data pendukung yang diperoleh dari berbagai sumber, yaitu Badan Pusat Statistik (BPS), Kementerian Pertanian (Kementan), Internet, hasil penelitian, artikel, jurnal, dan literatur yang relevan serta sumber informasi terkait lainnya yang mendukung penelitian. Pemilihan responden dilakukan dengan metode non probability sampling dimana menggunakan metode pendekatan purposive sampling. Sampel yang digunakan dalam penelitian merupakan petani padi yang sudah pernah mengikuti program AUTP di Kecamatan Banyusari dan Cilamaya
Wetan Kabupaten Karawang Jawa Barat. Ukuran sampel sebanyak 68 sampel dari responden-responden, dimana jumlah tersebut sudah memenuhi syarat minimum statistik.

\section{Metode Pegolahan dan Analisis Data}

Metode pengolahan data pada penelitian ini dilakukan secarakulitatif dan kuantitatif. Analisis kualitatif digunakan untuk mengkaji karakteristik petani padi di Kabupaten Karawang, seperti umur, tingkat pendidikan, luas lahan, status kepemilikan lahan, lama waktu menjadi petani padi dan sebagainya. Selanjutnya menguji sikap petani terhadap atribut AUTP akan diuji menggunakan analisis Fishbein. Formulasi model Fishbein (Engel et al., 1994) adalah sebagai berikut:

$$
A_{0}=\sum_{i=1}^{n} b_{i} e_{i}
$$

Dimana:

$\mathrm{A}_{0} \quad=$ sikap petani terhadap AUTP

$b_{i} \quad=$ kekuatan kepercayaan petani terhadap atribut $i$ dari AUTP

$e_{i} \quad=$ evaluasi petani terhadap atribut $i$ secara umum

$\mathrm{n} \quad=$ jumlah atribut

Untuk melihat sikap petani terhadap program AUTP, pengukurannya dengan melihat nilai sikap maksimum, netral dan minimum. Skor ideal adalah untuk setiap pertanyaan adalah 5 dan skor 
terendah adalah 1. Pengukurannya adalah sebagai berikut:

$\begin{aligned} \text { Maksimum } & =\text { nilai kepentingan } \\ & \text { tertinggi } \times \text { kinerja } \\ & \text { tertinggi } \times \text { jumlah } \\ & \text { atribut } \\ & =5 \times 5 \times 31 \\ & =775\end{aligned}$

Netral $=$ nilai kepentingan netral $\mathrm{x}$ kinerja netral $x$ jumlah atribut

$=3 \times 3 \times 31$

$=279$

Minimum $=$ nilai kepentingan minimum $\mathrm{x}$ kinerja minimum $x$ jumlah atribut$$
=1 \times 1 \times 31
$$$$
=31
$$

Analisis tingkat kepuasan petani terhadap

program

AUTP menggunakan analisis Customer Satisfaction Index (CSI). Cara untuk mengukur indeks ini dengan empat tahapan yaitu menghitung:

\section{Weighting Factors (WF)}

Wiighting Factors merupakan fungsi dari Mean Imprtance Score (MISi) masing-masing atribut atau indikator dalam bentuk persentase (\%) dati total Mean Importance Score (MIS-t) dari keseluruhan atribut yang diuji:

\section{WeightFactors}

$$
=\frac{\text { MISi }}{\text { TotalMISi }} \times 100 \%
$$

Dimana : I = atribut ke-i

\section{Weight Score (WS)}

Weight

Score

merupakan fungsi dari Mean

Satisfaction Score (MSS)

dikalikan dengan Weight

Factors (WF):

$$
\text { WS }=\text { MSS } x \text { WF }
$$

\section{Weight Avarage Total (WAT)}

Weight Avarage Total merupakan fungsi dari Total Weighted Score (WS) atribut ke- I (a-I) hingga atribut ke-n (a-n):

$$
\begin{gathered}
\text { WAT }=\text { Wsa-1 + WSa-2 + } \\
\text { Wsa-3...+ WSa-n }
\end{gathered}
$$

\section{Costumer Satisfaction Index (CSI) \\ Customer Satisfaction} Index merupakan fungsi dari Weighted Avarage (WA) dibagi Highest Scale (HS) atau sklam maksimum yang akan dipakai dalam penelitian dikalikan 100 persen:

$$
\mathrm{CSI}=\frac{\mathrm{WA}}{\mathrm{HS}} \boldsymbol{x} 100 \%
$$

Dalam penelitian ini kepuasan petani yang dimaksudkan dalam perhitungan dengan pengukuran kinerja. Tingkat kepuasan responden secara menyeluruh akan dilihat dari kriteria tingkat kepuasan. 
Kepuasan tertinggi dicapai bila CSI menunjukan $100 \%$. Rentang kepuasan berkisar dari 0-100\%. Berdasarkan Simamora (2005), untuk membuat skala linier numerik, ditentukan rentang skala (RS) terlebih dahulu dengan rumus:

$$
\mathbf{R S}=\frac{\mathbf{m}-\mathbf{n}}{\mathbf{b}}
$$

Dimana:

$\mathrm{RS}=$ rentang skala

$\mathrm{m} \quad=$ skor tertinggi

$\mathrm{n}=$ skor terendah

b =jumlah kelas (dalam penelitian ini akan digunakan lima kategori kelas)

Untuk penelitian ini, rentang skalanya adalah:

$$
\mathbf{R S}=\frac{\mathbf{1 0 0} \%-\mathbf{0} \%}{\mathbf{5}}=\mathbf{2 0} \%
$$

Berdasarkan rentang skala tersebut, maka kriteria kepuasannya adalah sebagai berikut:

1. $0<\mathrm{CSI} \leq 20 \%$ berarti sangat tidak puas

2. $20 \%<\mathrm{CSI} \leq 40 \%$ berarti tidak puas

3. $40 \%<\mathrm{CSI} \leq 60 \%$ berarti cukup puas

4. $60 \%<\mathrm{CSI} \leq 80 \%$ berarti puas

5. $80 \%<$ CSI $\leq 100 \%$ berarti sangat puas

Untuk melihat hubungan sikap dan kepuasan petani menggunakan analisis korelasi spearman dengan rumus:

$$
\rho=1-(6 \Sigma b i 2: N(N 2-1)
$$

Dimana :

$\boldsymbol{\rho}=$ koofisien korelasi spearman

$\mathrm{di}=$ beda antara sikap dan kepuasan

$\mathrm{N}=$ total pengamatan

Atribut yang diteliti sebanyak 31 atribut AUTP yang diambil berdasarkan Pedoman Bantuan Premi Asuransi Usahatani Padi Tahun 2016. Atribut tersebut dikelompokan bedasarkan bauran pemasaran 7P. Bauran pemasaran 7P terdiri dari product (produk), price (harga), place (tempat), promotion (promosi), process (proses), physical environment (lingkungan fisik) dan people (manusia). Atribut produk AUTP adalah pedoman, sumber risiko (kekeringan, banjir dan serangan OPT), syarat mengajukan klaim, pencairan klaim maksimal 14 hari setelah pengajuan, kerusakan yang bisa diajukan klaim $75 \%$ atau lebih dan pengajuan klaim setelah 11 hari tanam.atribut tempat adalah kemudahan mendapatkan informasi, kemudahan mengajukan klaim dan kemudahan penerimaan klaim. Atribut proses adalah pendaftaran, prosedur pengajuan klaim dan pencairan dana klaim. Atribut lingkungan fisik adalah formulir pendaftaran, formulir pemberitahuan kerusakan dan formulir berita acara pemeriksaaan kerusakan. Atribut harga adalah premi, subsidi premi dan jumlah klaim. Atribut promosi adalah sosialisasi langsung atau pertemuan, pengumuman di mesjid, leaflet, spanduk atau baliho, 
koran atau majalah, radio atau telivisi dan internet. Atribut stakeholder adalah Penyuluh Pertanian Lapang (PPL), Pengendali Organisme Pengganggu Tumbuhan Hama Penyakit (POPT-PHT), karyawan Jasindo, ketua kelompok tani, dinas pertanian, Unit Pelaksana Teknis Daerah (UPTD) pertanian.

\section{HASIL DAN PEMBAHASAN}

Profil petani responden pada penelitian ini dikaji berdasarkan jenis kelamin, umur, tingkat pendidikan, pekerjaan sebagai petani, luas lahan, status lahan, frekuensi mengikuti AUTP, pernah/belum mengajukan klaim dan pernah/belum menerima klaim. Sebagian besar responden adalah laki-laki (94\%) dengan sebaran usia paling banyak adalah 41-50 tahun (35\%). Petani yang berumur muda dan berpendidikan tinggi lebih mendukung pada program asuransi pertanian serta mempunyai kemampuan untuk membayar premi (Enjolras et al., 2012). Bertani merupakan pekerjaan utama responden (97\%) dengan pekerjaan sampingan selain petani adalah pedagang, pegawai desa, peternak dan sebagai buruh tani. Pendapatan rata-rata perbulan selain bertani adalah lebih dari $\mathrm{Rp}$ 2.000.000,- per bulan (53\%). Pendapatan petani signifikan mempengaruhi keikutsertaan petani dalam asuransi pertanian (Kumar 2013). Pendidikan terkahir petani responden pada umunya adalah tingkat SD atau sederajat (52\%). tingkat pendidikan adalah faktor yang signifikan mempengaruhi petani untuk mengikuti asuransi pertanian (Wang, 2003).

Luas lahan yang dikelola oleh petani responden sebagian besar adalah antara 1 ha -2 ha $(41 \%)$. Lahan yang dikelola oleh petani sebagian besar adalah milik sendiri (65\%). Ukuran usahatani dan status kepemililkan lahan mempengaruhi petani untuk mengikuti asuransi pertanian secara signifikan (Abulhasan et al., 2010). Petani yang menerima klaim Asuransi Usaha Tani Padi akibat gagal panen hanya empat orang $(6 \%)$ dari enam orang $(9 \%)$ yang pernah mengajukan klaim. Frekuensi petani responden dalam mengikuti Asuransi Usaha Tani Padi (AUTP) sebagian besar satu kali (72\%) yaitu baru mendaftar pada akhir tahun 2017 atau awal tahun 2018.

\section{Analisis Sikap Petani Terhadap Atibut Asuransi Usaha Tani Padi (AUTP)}

Perilaku

konsumen merupakan tindakan yang langsung terlibat dalam pendapatan, mengkomsumsi dan menghabiskan produk dan jasa, termasuk proses keputusan yang mendahului dan mengikuti tindakan ini (Engel et al. 1994). Sikap dilahirkan dari evaluasi konsumen setelah malakukan pembelian, bahwa produk (barang atau jasa) memberikan manfaat yang dibutuhkan untuk membantu memuaskan kebutuhannya. Petani responden dalam proses keputusan untuk mengikuti Asuransi Usaha Tani 
Padi (AUTP) melalui lima tahapan yaitu tahapan pengenalan kebutuhan, pencarian informasi, evaluasi alternatif, keputusan pembalian dan tahapan pasca pembelian.

Petani memerlukan motivasi atau faktor pendorong untuk mengikuti program AUTP. Oleh karena itu, perlu diketahui motivasi atau alasan utama petani dalam mengikuti program AUTP, serta sejauh mana petani menilai penting atau manfaat dari program AUTP tersebut. Berdasarkan hasil penelitian petani responden termotivasi untuk mengikuti program AUTP karena direkomendasikan oleh ketua kelompok tani (40\%). Motivasi lain yang disampaikan oleh petani adalah karena direkomendasikan oleh penyuluh pertanian serta untuk mengurangi risiko dalam berusahatani padi. Berbeda dengan penelitian Ghalavan et al., (2012), faktor yang mempengaruhi petani untuk bergabung dengan asuransi pertanian di Iran adalah pendapat pemimpin atau pemerintah. Petani menilai bahwa mengikuti program AUTP sangat penting (53\%). Menurut petani dengan mengikuti program AUTP membantu petani melakukan usahatani dengan baik, karena ada standar usahatani yang di tetapkan oleh pihak PT Jasindo misalnya sistem tanam harus legowo serta sistem pengairan yang tepat.

Informasi mengenai program AUTP baik berupa syarat untuk mengikuti, manfaat yang diperoleh serta bagaimana proses pendaftaran hingga mengajukan klaim akan mempengaruhi petani responden dalam mengambil keputusan untuk ikut atau tidaknya program tersebut. Hasil penelitian menunjukan bahwa sumber informasi mengenai program AUTP petani responden dapatkan melalui ketua kelompok tani (60\%), PPL (36\%) dan sisanya dari dinas pertanian dan UPTD setempat. Hal ini menggambarkan bahwa yang berperan aktif dalam sosialisasi tentang AUTP di Kabupaten Karawang adalah ketua kelompok tani dan PPL.

Pada tahap proses evaluasi alternatif petani responden menetapkan kriteria-kriteria yang sesuai dengan keinginannya agar dapat membuat keputusan pembelian, dengan membandingkan kinerja dari sejumlah atribut penting dari berbagai penawaran, menilai risiko terkait dan mengembangkan ekspektasi tingkat layanan AUTP yang diinginkan. atribut AUTP yang dipertimbangkan oleh petani untuk mengikuti program AUTP adalah sosialisasi dari ketua kelompok tani $(56 \%)$, sosialisasi dari PPL (29\%), sumber risiko berupa banjir kekeringan dan serangan OPT (6\%), jumlah klaim (6\%) dan sosialisai dari pihak Jasindo (3\%). Hal ini menunjukan bahwa sosialisasi ketua kelompok tani menentukan pemilihan alternatif, petani anggota akan ikut mendaftar program AUTP jika ketua kelompok mereka juga ikut mendaftar, bahkan ketua kelompok tani juga berinisiatif membayarkan premi anggotanya dengan uang kelompok atau uang pribadi agar semua anggotanya bisa terdaftar dalam program AUTP. Petani responden juga 
mendaftar AUTP karena sosialisasi dari PPL yang menjelaskan tentang manfaat yang diterima jika petani mengikuti program AUTP.

Petani responden memutuskan untuk mengikuti program AUTP dengan cara terencana (84\%) dan tidak terencana (16\%). Terencana maksudnya adalah petani dengan kesadaran sendiri mendaftarkan diri kepada ketua kelompok tani untuk mengikuti program AUTP dengan syarat-syarat yang telah ditentukan oleh pihak Jasindo seperti fotocopy KTP, surat keterangan luas lahan yang akan didaftarkan dan yang lainnya. Hal ini berarti petani sudah menyadari manfaat dari program AUTP yaitu mengurangi risiko usahatani padi yang mereka usahakan sebagai pekerjaan utama. Sedangkan petani yang mengikuti program AUTP dengan cara tidak terencana umumnya mereka didaftarkan oleh ketua kelompok tani tanpa sepengetahuan anggota. Hal ini dilakukan oleh ketua kelompok tani untuk melindungi anggotanya, agar jika terjadi kegagalan panen anggotanya bisa menerima klaim AUTP untuk modal melakukan budidaya selanjutnya.

Petani responden melakukan evaluasi setelah mengikuti program AUTP, yaitu membandingkan antara harapan dengan layanan yang mereka terima. Petani merasa puas $(94 \%)$ atau sesuai dengan harapan sebelum mengikuti AUTP. Hal ini terlihat dari petani menyatakan akan mendaftar kembali program AUTP di musim tanam berikutnya (97\%). Berbeda dengan hasil penelitian Nurhananto dan Mutiara (2016) bahwa respon petani terhadap indikator minat mengikuti program asuransi pertanian secara berkelanjutan adalah negatif.

Untuk melihat sikap petani terhadap atribut AUTP digunakan model multiatribut Fishbein. Model ini bisa memberikan gambaran tentang produk yang dinilai baik atau buruknya oleh konsumen dengan mempertimbangkan atribut-atribut yang dimiliki oleh produk. Atribut AUTP yang dinilai paling penting oleh petani adalah stakeholder PPL, namun tingkat kinerjanya dinilai cukup puas. Untuk itu, perlu ditingkatkan peran PPL dalam sosialisasi atau memberikan infromasi yang lengkap tantang program kepada petani atau kelompok tani, agar semakin banyak petani yang mau bergabung dengan program AUTP. Sejalan dengan penlitian Ghalavan (2012) salah satu upaya yang bisa dilakukan oleh pihak asuransi agar petani mau bergabung dengan program asuransi petanian adalah akses serta sosialisai atau saluaran komunikasi yang baik kepada petani.

Atribut terpenting kedua menurut petani adalah jumlah klaim atau ganti rugi dan sosialisasi langsung atau pertemuan yang termasuk kategori sangat penting. Tingkat kinerja atribut jumlah klaim dinilai cukup puas. Petani berharap klaim asuransi pertanian per hektar lebih besar dari Rp 6.000.000,- karena, menurut petani modal untuk usahatani per hektar adalah 7 -8 juta. Salah satu 
fungsi asuransi pertanian adalah memberikan keamanan berupa ganti rugi terhadap kerugian finansial petani yang diakibatkan oleh bencana alam, perubahan iklim, dan risiko harga (Epitemehin 2011; Nnandi at al., 2013). Sejalan dengan penelitian Swain (2014) dan Deng et al. (2008) yang menyatakan asuransi pertanian dibutuhkan untuk menstabilkan pendapatan petani, perekeonomian keluarga petani, serta mengurangi hutang dan risiko kegagalan. Tingkat kinerja atribut sosialisasi langsung adalah tidak puas. Harapan petani adalah dengan adanya sosialisasi langsung akan terbangun komunikasi dua arah antara petani dengan pihak asuransi, sehingga petani mempunyai kesempatan untuk mengetahui dengan jelas tentang program AUTP. Sosialiasi dengan komunikasi dua arah mempengaruhi tingkat partisipasi petani untuk mengikuti program AUTP (Wahyudi 2015). Sosialisasi langsung kepada konsumen dengan sikap baik dan ramah serta pemahaman yang baik dari pihak asuransi merupakan salah satu faktor yang mempengaruhi penilaian masyarakat terhadap perusahaan asuransi (Marwa et al., 2014).

Peran ketua kelompok tani dalam sosialiasi program AUTP merupakan atribut terpenting keempat menurut petani responden. Dalam pelaksanaan AUTP, ketua kelompok tani bisa dikatakan sebagai agen asuransi pertanian karena berperan untuk sosialisasi program kepada anggota kelompok tani. Dalam jasa asuransi agen merupakan ujung tombak untuk menarik nasabah. Nilai sikap ketua kelompok tani adalah memuaskan menurut petani responden. Ketua kelompok tani adalah orang yang mempengaruhi petani untuk mengikuti program AUTP yang sudah dibahas pada tahap proses pembalian jasa asuransi pertanian.

Atribut terpenting kelima adalah kemudahan untuk mendapatkan informasi. Nilai sikap kemudahan untuk mendapatkan informasi adalah cukup memuaskan. Informasi yang lengkap tentang cara serta syarat untuk mendaftar, syarat untuk mangujukan, prosedur mengajukan klaim serta manfaat yang akan diperoleh jika mengikuti program AUTP sangat dibutuhkan untuk petani mau serta mengajak petani lain untuk bergabung dengan program AUTP. Kemudahan akses nasabah terhadap asuransi pertanian merupakan faktor yang signifikan mempengaruhi petani untuk bergabung dengan asuransi pertanian (Abulhasan et al., 2010).

Atribut yang dinilai tidak terlalu penting (berdasarkan nilai terendah tingkat kepentingan) adalah promosi melalui internet. Petani menilai bahwa promosi di internet kurang efektif karena jarang sekali petani menggunakan internet sebagai sumber informasi. Hal ini juga didukung oleh tingkat pendidikan petani yang relatif rendah dan umur petani sebagian besar diatas 40 tahun. Enjolras et al. (2012) mengatakan petani yang berumur muda dan berpendidikan tinggi lebih mendukung 
pada program asuransi pertanian. Tingkat kepentingan dan kinerja lebih

Atribut yang sangat perlu ditingkatkan kinerjanya adalah promosi (pengumuman di Mesjid, leaflet, spanduk/baliho, radio/televisi) dan peran Stakeholder karyawan Jasindo. Menurut petani responden promosi dengan pengumuman di mesjid adalah penting, namun tingkat kinerja atribut dinilai tidak memuaskan. Artinya promosi AUTP melalui pengumuman di Mesjid nilai di lokasi penelitian belum berjalan dengan baik. Promosi melalui media leaflet dinilai penting, namun tingkat kinerjanya sangat tidak puas. Promosi melalui spanduk atau baliho juga dinilai penting oleh petani dengan tingkat kinerja adalah sangat tidak puas. Spanduk atau baliho merupakan alat promosi yang tidak asing lagi bagi petani. Sentra area pertanian seperti sawah dan kebun, telah banyak kita temui baliho promosi pupuk, pestisida dan benih dari perusahaan swasta. Radio dan Televisi merupakan sarana hiburan yang sering di dengar dan di tonton oleh masyarakat Indonesia. Oleh karena itu petani menilai tingkat kepentingan promosi melalui media radio atau televisi adalah penting. Namun tingkat kinerja atribut dinilai tidak puas oleh petani. Artinya petani responden menginginkan adanya promosi tentang AUTP di media radio atau televisi, karena waktu senggang dan istirahat petani sering dimanfaatkan untuk menonton televisi, sehingga lebih banyak lagi petani padi yang mengetahui tentang adanya rinci dapat dilihat pada Lampiran1.

program AUTP. Adapun sumberSumber informasi konsumen menurut Kotler (2005) adalah sumber pribadi (keluarga,teman, tetangga, kenalan), sumber komersial (iklan), sumber publik ( media masa) dan sumber pengalaman (penanganan, pemeriksaan dan pemakaian produk). Karyawan Jasindo berhubungan langsung dengan petani dalam melakukan pemeriksaan dan perhitungan kerusakan. Tingkat kepentingan atribut karyawan Jasindo adalah sangat penting, namun kinerja atribut dinilai sangat tidak memuaskan. Artinya, petani responden sebagian tidak merasakan peran karyawan Jasindo selama mereka mengikuti AUTP, hal ini dikarenakan pihak Jasindo selaku perusahaan yang ditunjuk pemerintah dalam asuransi pertanian belum melakukan sosialisasi langsung terkait program AUTP di lokasi penelitian. Hasil ini sejalan dengan penelitian Wahyudi (2015) yang menyampaikan bahwa keaktifan PT Petrokimia Gresik selaku pihak yang ditunjuk oleh pemerintah untuk menjalankan mekanisme ujicoba AUTP mempengaruhi tingkat partisipasi petani dalam pelaksanaan program AUTP. Total penilaian sikap $\left(\mathrm{A}_{0}\right)$ petani terhadap AUTP adalah 344,7 berada diatas nilai sikap netral yaitu 279 dan dibawah sikap maksimum.

\section{Analisis Customer Satisfaction Index}

Indeks kepuasan petani terhadap atribut AUTP sebesar 
$51,82 \%$, nilai tersebut berada pada rentang antara 40 sampai dengan 60 yang berarti petani cukup puas terhadap kinerja ada pada atributatribut AUTP. Hal ini menunjukan bahwa kinerja atribut-atribut yang ada pada AUTP cukup baik dan cukup memuaskan petani pesera AUTP. Tentu saja indeks kepuasan ini harus ditingkatkan hingga mendekati $100 \%$ atau sangat memuaskan, sehingga semakin banyak petani yang mau bergabung dan merasakan manfaat dari AUTP yaitu memperoleh ganti rugi keuangan yang akan digunakan sebagai modal kerja usahatani untuk pertanaman berikutnya, meningkatkan aksebilitas petani terhadap sumbersumber pembiayaan dan mendorong petani untuk menggunakan input produksi sesuai anjuran usahatani yang baik. Lebih lengkap kepuasan petani terhadap AUTP dapat dilihat pada Lampiran 2.

\section{Hubungan Sikap dan Kepuasan Petani Peserta AUTP}

Sikap merupakan evaluasi yang dilakukan oleh konsumen yang memungkinkan untuk memberikan respon positif atau negatif berkenaan dengan objek yang diberikan. Pengukuran sikap bagi pemasar merupakan hal yang penting, untuk mengidentifikasi manfaat, mengembangkan produk, evaluasi serta strategi pemasaran produk. Sikap konsumen terhadap suatu produk mempengaruhi perilaku atau tindakan konsumen terhadap produk tersebut. Sedangkan kepuasan akan diperoleh oleh konsumen ketika evaluasi pasca komsumsi setidaknya memenuhi atau melebihi harapannya. Bila kinerja melebuhi harapan konsumen akan merasa puas, sebaliknya bila kinerja tidak sesuai dengan harapan maka konsumen tidak puas. Untuk melihat hubungan antara sikap dan kepuasan petani dalam mengikuti program AUTP, dilakukan analisis korelasi spearman. Hasil yang diperoleh adalah nilai $\mathrm{Z}$ hitung pada korelasi spearman lebih besar dari pada $\mathrm{Z}$ tabel yaitu 0,969 pada derajat kesalahan $0,01 \%$. Kita bisa menafsirkan bahwa sikap mempengaruhi kepuasan petani secara signifikan dalam mengikuti program AUTP.

Meningkatkan nilai sikap petani terhadap atribut AUTP dengan meningkat kinerja, terutama pada atribut yang sangat penting menurut petani seperti PPL, sosialisasi langsung, ketua kelompok tani, akan mempengaruhi tingkat kepuasan petani terhadap kinerja program AUTP. Petani yang merasa puas dengan program AUTP akan memberitahukan tentang manfaat program kepada petani yang belum bergabung, sehingga akan semakin banyak petani yang akan mau dan merasakan manfaat dari program AUTP. Hasil uji korelasi spearman menggunakan SPSS 13.0 dapat dilihat pada Lampiran 3.

\section{SIMPULAN DAN SARAN Simpulan}

Kesimpulan yang dapat ditarik berdasarkan hasil dan pembahasan diatas adalah sikap petani terhadap AUTP berada antara nilai sikap netral 
dan nilai sikap maksimum. Atribut yang paling penting menurut petani responden adalah stakeholder PPL, jumlah klaim, sosialisasi langsung, peran ketua kelompok tani, dan kemudahan untuk mendapatkan informasi. Ketua kelompok tani merupakan sumber informasi dan motivasi petani dalam mengikuti program AUTP. Kepuasan petani secara keseluruhan terhadap kinerja atribut AUTP adalah pada tingkat belum puas. Korelasi sikap dan kepuasan petani dalam mengikuti program AUTP adalah sangat signifikan.

\section{Saran}

Atribut-atribut yang dinilai sangat tidak memuaskan oleh petani adalah peran stakeholder karyawan Jasindo, petan UPTD serta atribut promosi melalui sosialisasi langsung, pengumuman di mesjid, Leaflet, spanduk atau baliho, dan radio atau televisi. Oleh karena itu, Kementerian Pertanian selaku pembuat kebijakan dan PT. Jasindo sebagai pihak asuransi perlu untuk meningkatkan kinerja atribut-atribut yang dinilai penting oleh petani yaitu stakeholder PPL, jumlah klaim, sosialisasi langsung, peran ketua kelompok tani, dan kemudahan untuk mendapatkan informasi, untuk menciptakan sikap yang posistif serta meninglkatkan kinerja atribut yang sangat tidak memuaskan petani untuk meningkatkan kepuasan petani terhadap program AUTP.

\section{DAFTAR PUSTAKA}

Abolhasan SS, Ghobadi FR, Abolghasem SS, Mohamadi Y, Sharifi O and Asakereh A. 2010. Survey Of Effective Factors On Adoption Of Crop Insurance Among Farmers: A case study of Behbahan County. African Journal of Agricultural Research. Vol. 5(16), pp. 2237-2242.

Deng X, Barnett B, Hoogenboom G, Yu Y and Garcia A. 2008. Alternative Crop Insurance Indexes. Journal of Agricultural and Applied Economics, 40,1 (April 2008):223-237.

Direktorat Jendral Prasarana dan Sarana Pertanian. 2015. Pedoman Bantuan Premi Asuransi Usahatani Padi. Jakarta (ID). Direktorat Jendral Prasarana dan Sarana Pertanian.

Engel, James F, Roger DB, Paul WM. 1994. Perilaku Konsumen. Edisi Keenam. Jilid I. Binarupa Aksara. Jakarta.

Enjolras G, Capitanio F, Adinolfe F. 2012. The Demand for Crop Insurance : Conbined Approaches for France and Italy. Agricultural Economics Review. Vol.13. No. 1. 
Epetimehin, Fesrus M. 2011. Research Article Agricultural Insurance IN nigeria and Its Economic Impact. International Journal of Current ResearchVol. 3, Issue, 12, pp.233-238.

Ghalavand K, Karim MH and Hashem A. 2012. Agriculture Insurance as a Risk Management Strategy in Climate Change Scenario:A study in Islamic Republic of Iran. International Journal of Agriculture and Crop Sciences Vol., 4(13), 831-838.

Insyafiah, Wardhani I. 2014. Kajian Persiapan Implementasi Asuransi Pertanian Secara Nasional. Jakarta (ID) : Badan Kebijakan Fiskal Pusat Pengelolaan Risiko Fiskal (Kementrian Keuangan).

Kotler P. 2005. Manajemen Pemasaran, Jilid 1 dan 2. Jakarta (ID). PT Indeks.

Kumar R. 2013. Crop InsuranceTribulations And Prospects Of Farmers With Reference To Nuzvid, Krishna District. International Journal of Marketing, Financial Services \& Management ResearchISSN 2277- 3622 Vol.2, No. 9.

Marwa S, Sumarwan U, Nurmalina R. 2014. Bauran Pemasaran Memengaruhi Keputusan
Pembelian Asuransi Jiwa

Individu. Keluarga dan Konseling. ISSN 1907-6037. Pp 183-192.

Nnadi FN, Chikaire J, Echetana JA, Ihenacho RA, Umunnakwe PC, and Utazi CO. 2013. Agricultural insurance: A strategic tool for climate change adaptation in the agricultural sector. Net Journal of Agricultural Science Vol. 1(1), pp. 1-9.

Nurhananto AD dan Mutiara F. 2016. Respon Petani Terhadap Asuransi Pertanian di Kecamatan Kepanjen Kabupaten Malang. Malang: Seminar Nasional Pembangunan Pertanian.

Pasaribu MS. 2016. Risiko Produksi Pangan : Tantangan dan Peluang. Bogor (ID) : Pusat Analisis Sosial Ekonomi dan Kebijakan Pertanian. Badan Litbang Pertanian Bogor.

Simamora. 2002. Panduan Riset Perilaku Konsumen. Jakarta [ID]. PT Gramedia Pustaka Utama.

Swain M. 2014. Crop Insurance for Adaptation to Climate Change in India. Asian reserch Center.

Wahyudi I. 2015. Skim Ujicoba Asuransi Usahatani Padi dan 
Faktor-Faktor

Berhubungan

yang

Partisipasi

Dengan

Program AUTP. [Tesis].

Program Pascasarjana Institut

Pertanian Bogor, Bogor.
Wang HH, Hanson DH, Black RJ. 2003. Efficiency Costs of Subsidy Rules For Crop Insurace. Journal of Agricultural and Resource Economics. 28(1) : 116-137. 


\section{LAMPIRAN}

Lampiran 1. Tingkat kepentingan dan kinerja atribut AUTP

\begin{tabular}{lccc}
\hline \multicolumn{1}{c}{ Atribut } & Kepentingan(ei) & Kinerja(bi) & (bi.ei) \\
\hline PPL & 4.91 & 3.20 & 15.75 \\
\hline Sosialisasi langsung/ pertemuan & 4.90 & 2.50 & 12.24 \\
\hline jumlah klaim & 4.90 & 2.95 & 14.48 \\
\hline ketua kelompok tani & 4.88 & 3.69 & 18.02 \\
\hline kemudahan untuk mendapatkan informasi & 4.84 & 2.75 & 13.31 \\
\hline Pengumuman di Mesjid & 3.59 & 1.79 & 6.438 \\
\hline Leaflet & 3.47 & 1.88 & 6.533 \\
\hline Spanduk/baliho & 4.00 & 1.57 & 6.294 \\
\hline Radio/Televisi & 3.94 & 1.72 & 6.781 \\
\hline Karyawan jasindo & 4.76 & 1.49 & 7.077 \\
\hline Internet & 3.03 & 1.98 & 6.014 \\
\hline
\end{tabular}


Lampiran 2. Perhitungan Customer Satisfaction Index AUTP

\begin{tabular}{rlrrrr}
\hline \multicolumn{1}{c}{ Atribut } & MIS & MSS & WF & WS \\
\hline 1 & pedoman & 4.46 & 2.28 & 0.034 & 0.076 \\
\hline 2 & sumber risiko (banjir, kekeringan \& OPT) & 4.15 & 3.06 & 0.031 & 0.095 \\
\hline 3 & syarat mengajukan klaim & 4.04 & 2.50 & 0.030 & 0.076 \\
\hline 4 & pencarairan klaim max 14 hari setelah pengajuan & 4.82 & 2.40 & 0.036 & 0.087 \\
\hline 5 & kerusakan yang bisa diajukan kalim 75\% atau lebih & 4.49 & 2.68 & 0.034 & 0.090 \\
\hline 6 & pengajuan klaim setelah 11 hari tanam & 4.34 & 2.93 & 0.033 & 0.095 \\
\hline 7 & kemudahan untuk mendapatkan informasi & 4.84 & 2.75 & 0.036 & 0.100 \\
\hline 8 & kemudahan mengajukan klaim & 4.54 & 2.65 & 0.034 & 0.090 \\
\hline 9 & kemudahan penerimaan klaim & 4.57 & 2.54 & 0.034 & 0.087 \\
\hline 10 & Pendaftaran & 4.63 & 3.62 & 0.035 & 0.126 \\
\hline 11 & prosedur pengajuan klaim & 4.22 & 2.72 & 0.032 & 0.086 \\
\hline 12 & pencairan dana klaim & 4.51 & 2.47 & 0.034 & 0.084 \\
\hline 13 & formulir pendaftaran & 3.56 & 3.07 & 0.027 & 0.082 \\
\hline 14 & fomulir pemberitahuan kerusakan & 3.91 & 2.53 & 0.029 & 0.074 \\
\hline 15 & formulir berita acara pemeriksaan kerusakan & 3.81 & 2.53 & 0.029 & 0.072 \\
\hline 16 & Premi & 4.49 & 3.49 & 0.034 & 0.118 \\
\hline 17 & subsidi premi & 4.82 & 3.78 & 0.036 & 0.137 \\
\hline 18 & jumlah klaim & 4.90 & 2.96 & 0.037 & 0.109 \\
\hline 19 & Sosialisasi langsung/ pertemuan & 4.90 & 2.50 & 0.037 & 0.092 \\
\hline 20 & Pengumuman di Mesjid & 3.59 & 1.79 & 0.027 & 0.048 \\
\hline 21 & Leaflet & 3.47 & 1.88 & 0.026 & 0.049 \\
\hline 22 & Spanduk/baliho & 4.00 & 1.57 & 0.030 & 0.047 \\
\hline 23 & Koran/majalah & 3.19 & 1.87 & 0.024 & 0.045 \\
\hline 24 & Radio & 3.94 & 1.72 & 0.030 & 0.051 \\
\hline 25 & Internet & 3.03 & 1.99 & 0.023 & 0.045 \\
\hline 26 & PPL & 4.91 & 3.21 & 0.037 & 0.118 \\
\hline 27 & POPT & 4.10 & 2.07 & 0.031 & 0.064 \\
\hline 28 & karyawan jasindo & 4.76 & 1.49 & 0.036 & 0.053 \\
\hline 29 & ketua kelompok tani & 4.88 & 3.69 & 0.037 & 0.136 \\
\hline 30 & Dinas & 4.62 & 2.35 & 0.035 & 0.082 \\
\hline 31 & UPTD & 4.82 & 2.03 & 0.036 & $0, .074$ \\
\hline & $\mathbf{1 3 3}$ & $\mathbf{W A T}$ & $\mathbf{2 . 5 9 1}$ \\
\hline & & $\mathbf{5 1 . 8 2 \%}$ & & & \\
\hline Ketal & & & \\
\hline
\end{tabular}

\section{Keterangan:}

MIS (Mean Importance Score)

MSS (Mean on Satisfaction Score)

WF (Weighting Factors)

WS (Wieght Score)

WAT (Weiht Avarege Total)

CSI (Customer Satisfaction Index) 
Lampiran 3. korelasi spearman sikap dan kepuasan petani peserta AUTP

\section{Correlations}

\begin{tabular}{|l|l|l|r|r|}
\hline \multicolumn{2}{|l|}{} & \multicolumn{1}{c|}{ Sikap } & \multicolumn{1}{c|}{ Kepuasan } \\
\hline Spearman's rho & sikap & Correlation Coefficient & 1,000 &, $969\left(^{* \star}\right)$ \\
\hline & & Sig. (2-tailed) &. &, 000 \\
\hline & & N & 68 & 68 \\
\hline & kepuasan & Correlation Coefficient &, $969\left(^{* \star}\right)$ & 1,000 \\
\hline & & Sig. (2-tailed) &, 000 &. \\
\hline & & N & 68 & 68 \\
\hline
\end{tabular}

Correlation is significant at the 0.01 level (2-tailed). 